\title{
The process of consumption and natural gas prices in european countries in the aspect of the spread of the COVID-19 epidemic
}

ABSTRACT:As is well known, gas consumption and its prices depends on many factors including local factors, geopolitics, the development of the gas transport infrastructure (including liquefied natural gas), distribution and extraction costs - for example unconventional deposits (e.g. shale gas). The global gas market depends primarily on the economic relations between large gas producers and importers e.g. US-China, Middle East/US - Russia etc. (Olayele 2015). In individual countries, the price is also dependent on concluded contracts and delivery directions. Also it should be mentioned that the gas consumption depends on weather conditions, type of day of the year (holiday, business day, month) and economic situation (Kosowski et. al 2010). What impact has the appearance of the COVID-19 epidemic had on the European natural gas market?

The analyzed research problem concerned, in particular, two areas: gas consumption and its prices, in selected European countries in the aspect of the spread of the COVID-19 epidemic with reference to historical data from 2016-2019. Seven European countries belonging to the European Network of Transmission System Operators for Gas (ENTSOG) were selected, for which the highest inland consumption of natural gas by country was observed in the last year. The countries are presented in order or consumption: Germany, the United Kingdom, Italy, France, the Netherlands,

$\triangle$ Corresponding Author: Tomasz Chrulski; e-mail: chrulski@agh.edu.pl

1 AGH Drilling, Oil and Gas, University of Science and Technology, Kraków, Poland; ORCID iD: 0000-0002-8842518X; e-mail: chrulski@agh.edu.pl

2020. The Author(s). This is an open-access article distributed under the terms of the Creative Commons Attribution-ShareAlike International License (CC BY-SA 4.0, http://creativecommons.org/licenses/by-sa/4.0/), which permits use, distribution, and reproduction in any medium, provided that the Article is properly cited. 
Spain, Poland. The data has been downloaded from transmission system operators (TSOs) for each of these countries.

Furthermore the article showed information about the dates of governments restrictions (lockdown), LNG contract volumes, injection/withdrawal volumes (storage).

KeYwORDs: gas consumption, COVID-19, natural gas prices, lockdown

\section{Introduction}

The COVID-19 pandemic is a major shock to the global and European economy. The shock resulted from China's initial contraction in Q1 2020. The shock the European and global economy was caused by lower consumer demand and the negative impact of uncertainly on investment plants (EC 2020). In 2020, the EU is facing a 7-10\% economic downturn as a result of the Covid-19 global pandemic. The longer the crisis lasts, the higher the impacts will be felt in the economy, including in the energy sector. Maintaining energy security is critical, as the energy sector is vital for the health of the citizens and the economy and needs to continue functioning. The physical resilience of the EU energy sector has been strong however, its financial resilience is under severe stress (IEA 2020).

Electricity consumption in Europe is down roughly $10 \%$ since various policies have been implemented to slow the transmission of COVID-19 (University of Chicago 2020).

In Q1 2020 EU gas consumption decreased by 5\% in year-on-year comparison, in contrast to the increases in the previous two quarters ( $7 \%$ and $2 \%$ ). Gas-fired electricity generation decreased slightly (by $2 \%$, year-on-year), and milder than usual weather reduced heating needs in most of the EU countries. In absolute numbers, gas consumption in Q1 2020 amounted to 131 bcm (DG Energy 2020).

It should also be mentioned that the direction of delivery depends on the geopolitical situation. For example Nord Stream became the most important route of Russian pipeline gas to the EU in Q1 2020 (DG Energy 2020). reduce reduction of the export of Russian gas to the west through Ukraine was decided. This is due to the fact that Ukraine has accumulated massive gas reserves in national underground gas storage facilities, due to fears of possible earlier suspension of the gas stream through Ukrainian territory earlier this year (CNBC 2019). Another important aspect is the OPEC group's lack of agreement to extend and increase the cuts in the oil agreement, which may affect the price of gas (McKinsey \& Company 2020).

The oversupply on the gas market form abundant LNG send-outs and storage withdrawals, coupled with the decreasing demand for gas, resulted in significant price drops on the markets. By the end of March 2020 the TTF fell to lows not seen since 2009. The gas premium of the Asian markets shrunk to Europe and the TTF also decreased its price gap vis-a-vis the US Henry Hub (DG Energy 2020). All political relationships have an impact on the gas market. 
Seven European countries belonging to the European Network of Transmission System Operators for Gas (ENTSOG) were selected, for which the highest inland consumption of natural gas by country was observed in the last year. The countries are presented in order: Germany, the United Kingdom, Italy, France, the Netherlands, Spain, Poland. The data has been downloaded from transmission system operators (TSOs) for each of these countries (Table 1).

TABLE 1. Inland consumption (observed) of natural gas, by country, 2019 [TJ]

TABELA 1. Zużycie krajowe (zaobserwowane) gazu ziemnego, według kraju, 2019 [TJ]

\begin{tabular}{|c|c|c|c|c|c|c|c|}
\hline & \multicolumn{6}{|c|}{2019} & \multirow{2}{*}{$\begin{array}{c}2019 \\
\text { Cumulative } \\
\text { data }\end{array}$} \\
\hline & Jan & Feb & March & April & May & June & \\
\hline European Union & $2,528,882$ & $1,955,447$ & $1,810,105$ & $1,411,645$ & $1,279,538$ & $1,004,610$ & $9,990,227$ \\
\hline Euro area & $1,789,710$ & $1,382,422$ & $1,273,170$ & 981,704 & 911,241 & 714,190 & $7,052,437$ \\
\hline Germany & 93,134 & 70,022 & 64,866 & 51,411 & 47,674 & 38,387 & 365,494 \\
\hline United Kingdom & 15,720 & 12,548 & 11,224 & 9,684 & 7,941 & 6,866 & 63,983 \\
\hline Italy & 49,634 & 38,614 & 32,570 & 23,460 & 21,598 & 15,050 & 180,926 \\
\hline France & 15,805 & 12,233 & 11,966 & 8,786 & 8,252 & 5,951 & 62,993 \\
\hline Turkey & 2,845 & 2,042 & 2,030 & 1,285 & 993 & 613 & 9,808 \\
\hline Netherlands & 2,845 & 2,042 & 2,030 & 1,285 & 993 & 613 & 9,808 \\
\hline Spain & 19,670 & 16,050 & 18,932 & 18,543 & 18,432 & 16,563 & 108,190 \\
\hline Poland & 26,886 & 19,547 & 15,085 & 14,133 & 12,950 & 15,609 & 104,210 \\
\hline
\end{tabular}

Source: own study based on EUROSTAT.

\section{Lockdown}

The COVID-19 outbreak, which is now turning into a pandemic, is a global health crisis. However, the measures taken by countries against this epidemic bring along an unprecedented economic disaster. The COVID-19 global pandemic has been dealt with in many studies on the socio-economic effects of the world economy.

In Europe, SARS-CoV-2 began to spread rapidly from the beginning of March (Fig. 1). The first case of a patient with the virus appeared in Europe was France (January 27,2020). The virus was confirmed in a 48-year-old French citizen who came to France from China. Then virus were confirmed in Germany (January 27, 2020), Spain (January 31, 2020), United Kingdom (January 31, 2020), Italy (February 21, 2020), Netherlands (February 27, 2020) and Poland (March 4, 2020). In the countries mentioned, Poland was the fastest country that introduced restriction from the time the first virus case appeared until the restrictions were introduced (March 13, 
2020), contrary to the Netherlands what it took the longest (May 16, 2020). Additionally, in other countries: Germany (March 15, 2020), France (March 17, 2020), Spain (March 14, 2020), Italy (March 9, 2020), United Kingdom (March 16, 2020). It can be argued that after the restrictions introduced, the number of cases decreased (Fig. 2).

\section{Europe}

\section{4,796,426}

confirmed case

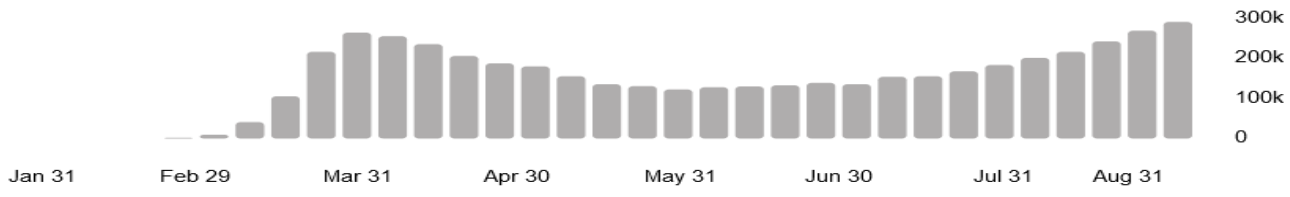

Fig. 1. Confirmed cases of COVID-19 in Europe (2020)

Source: own study based on WHO

Rys. 1. Potwierdzone przypadki zachorowań w Europie na COVID-19

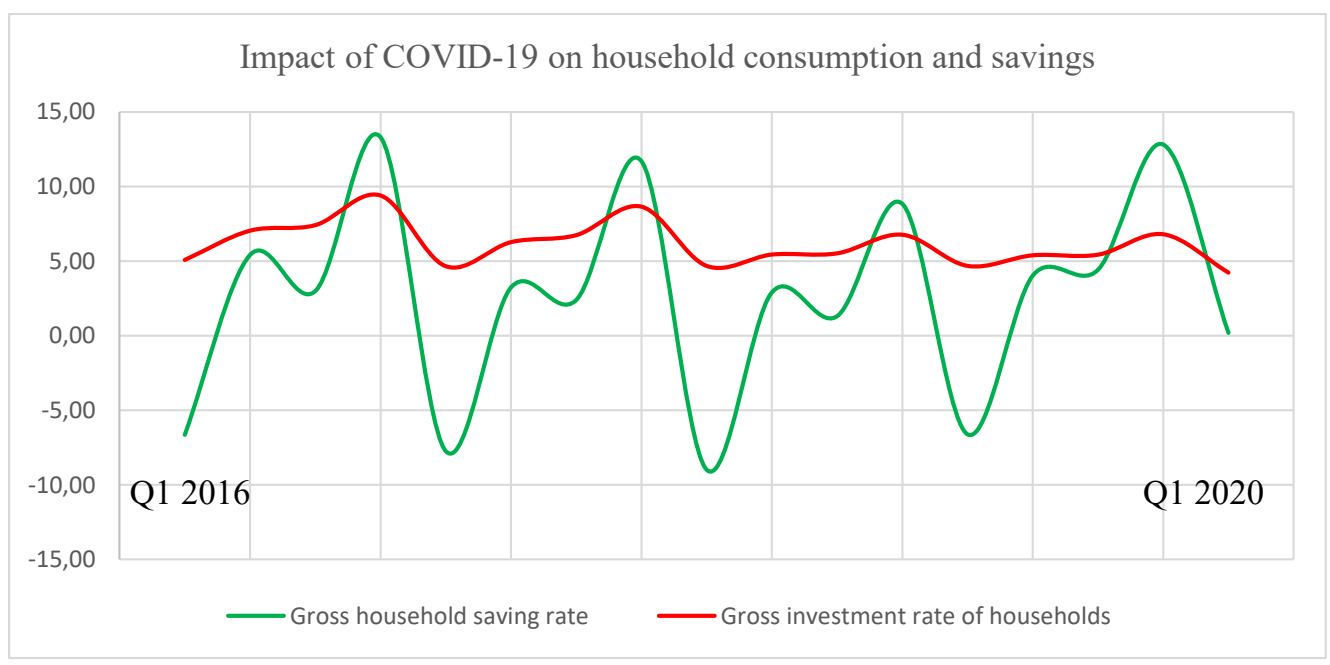

Fig. 2. Household consumption and saving rates 2016-2020

Source: own study based on EUROSTAT

Rys. 2. Współczynniki konsumpcji gospodarstw domowych oraz oszczędności 2016-2020

The household saving rate in the EU recorded its all-time highest year-over-year increase in Q1 2020 (+3.5 percentage points (pp) compared with Q1 2019.

The main reason is the marked year-over-year decrease of household final consumption expenditure $(-1.7 \%)$, in stark contrast with its recent increases above $2 \%$. Additionally, the increase of household gross disposable income $(+2.4 \%)$ also contributed to the increase of the saving rate (EUROSTAT 2020). 


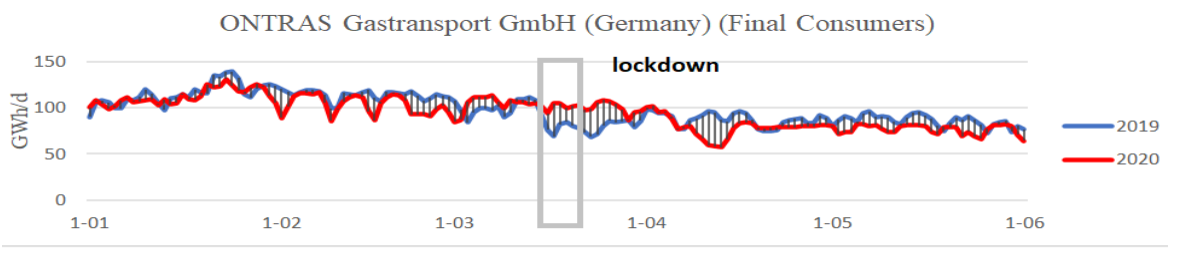

National Grid Gas plc (United Kingdom) (Final Consumers)

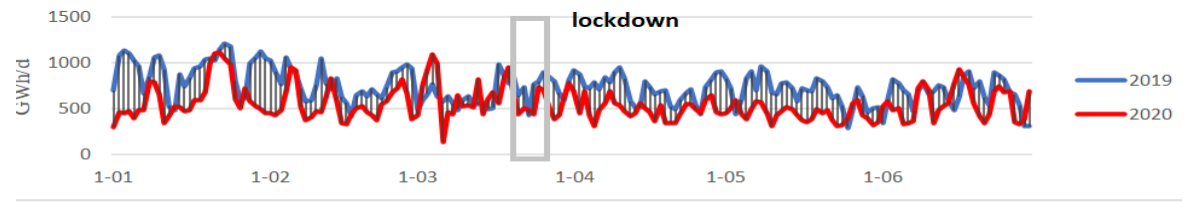

Industrial Consumers (Italy)|Thermal Plants (IT)

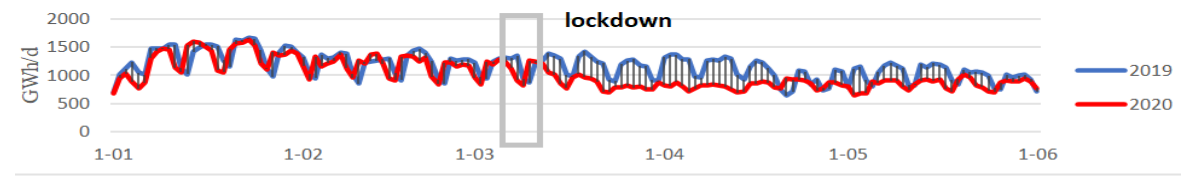

GRTgaz (France) (Final Consumers)

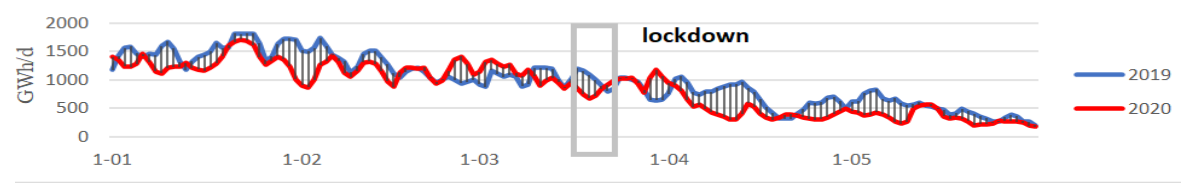

Gasunie Transport Services B.V. (Netherlands) (Final Consumers)
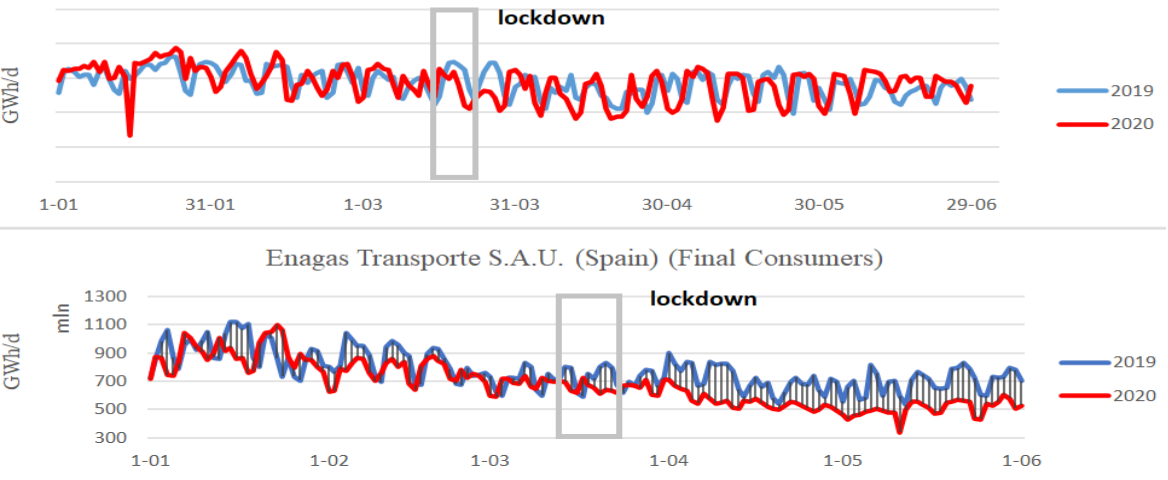

GAZ-SYSTEM S.A. (Poland) (Final Consumers)

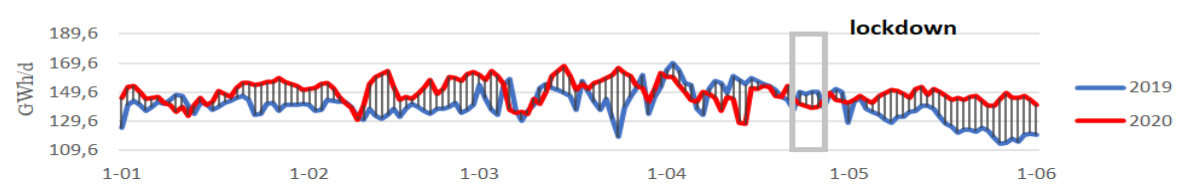

Fig. 3. Comparison of gas consumption in Q1 2019-2020 Source: own study based the ENTSOG

Rys. 3. Porównanie zużycia gazu ziemnego w pierwszym kwartale lat 2016-2020 


\section{Data used for analyses}

\subsection{Flow gas (2016-2020)}

Germany was the largest energy consumer in Europe and the seventh-largest energy consumer in the world in 2019 (BP 2020). In 2019, imports accounted for about 97\% of the total natural gas supply. Russia, the Netherlands, and Norway are the largest natural gas exporters to Germany (U.S. EIA 2020). Despite the COVID-19 epidemic, DE-GASPOOL is an upward trend in gas flows to other countries (Fig. 4). The above indicates that Germany maintains a high position as an importer and exporter of gas to neighboring countries. This may also be proved by the fact that NCG and Gaspool are scheduled to be combined into Trading Hub Europe from 1 October 2021 (Hedwedge 2020). However the chart (Fig. 4) showed lower volumes of gas transmitted to end consumers in Germany. Total impacts epidemic on Germany is about 2-5\% y-o-y (RBAC 2020).

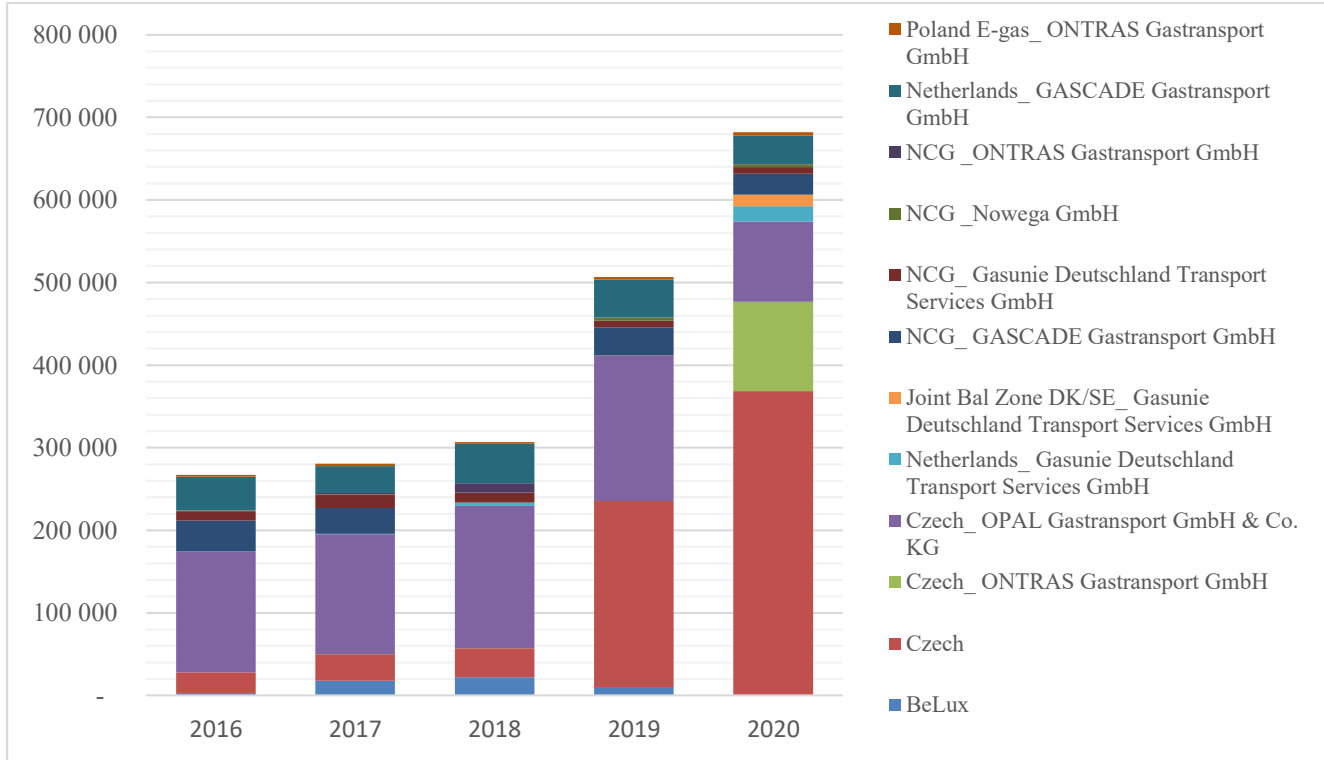

Fig. 4. Gas volumes at exit points for the German DE-GASPOOL [GWh/year] Source: own study based on ENTSOG

Rys. 4. Przesłane wolumeny gazu w punktach wyjścia dotyczące niemieckiego obszaru DE-GASPOOL [GWh/year] 


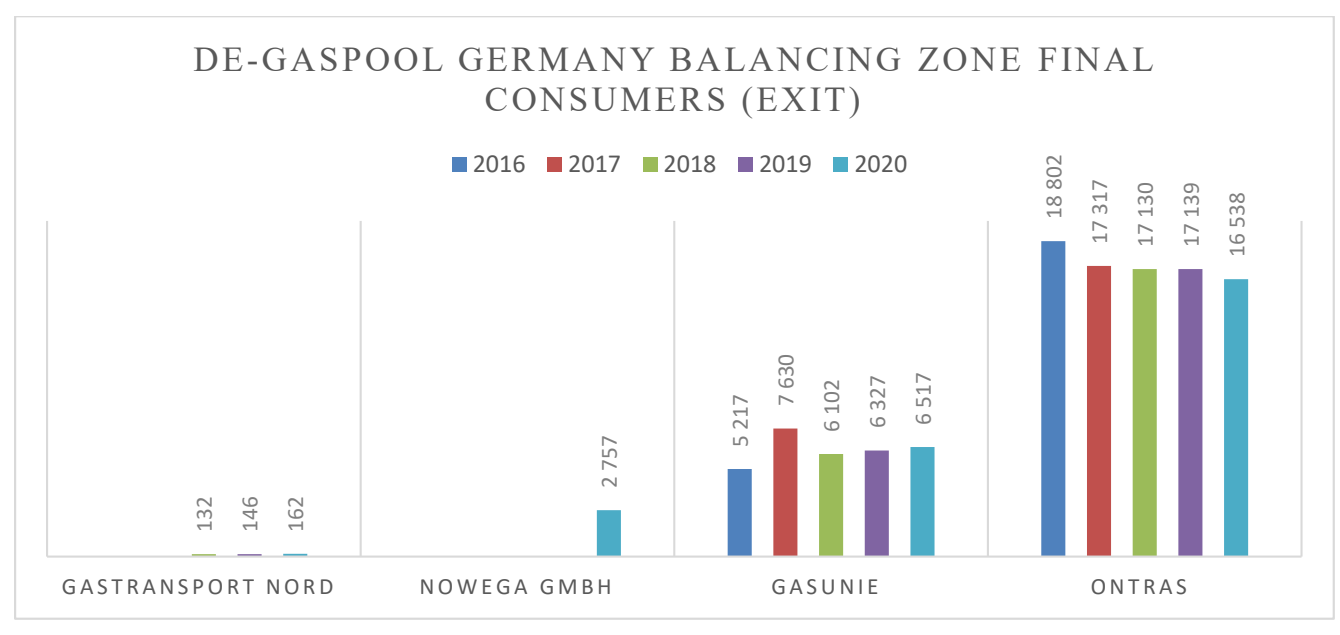

Fig. 5. Comparison of flow gas in H1 2016-2020 Source: own study based on ENTSOG

Rys. 5. Porównanie przepływów gazu dla pierwszego półrocza 2016-2020

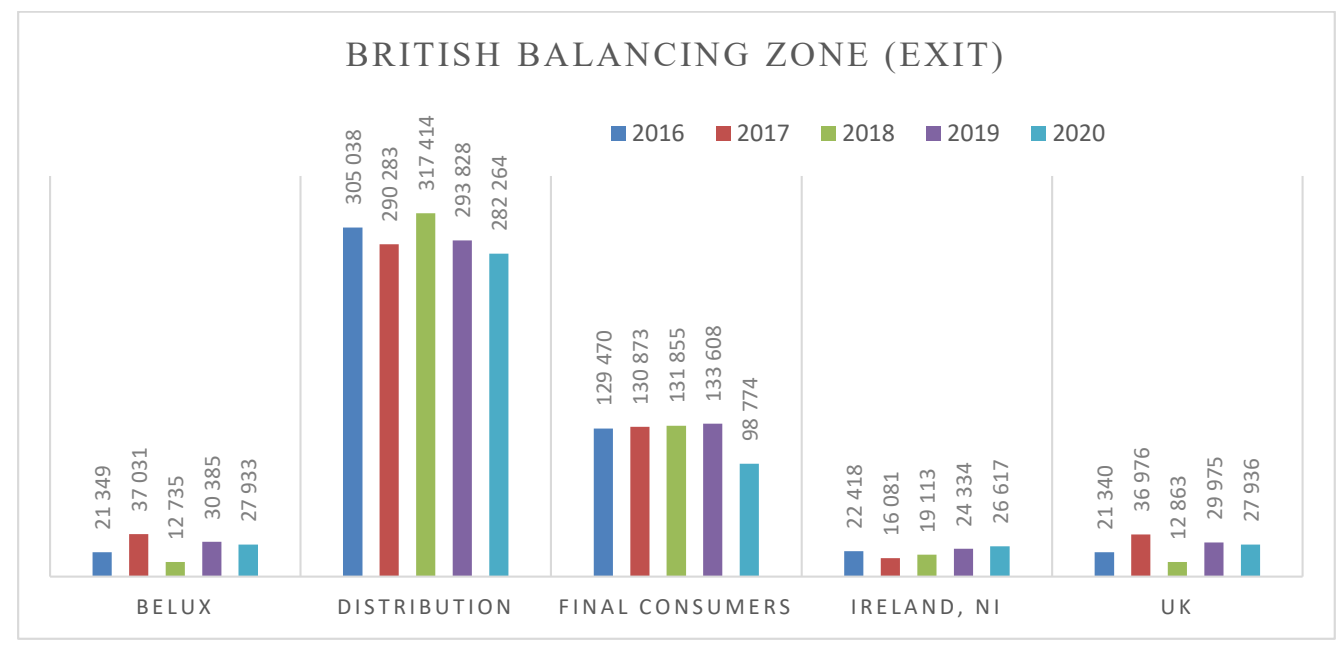

Fig. 6. Comparison of flow gas in H1 2016-2020 Source: own study based on ENTSOG

Rys. 6. Porównanie przepływów gazu dla pierwszego półrocza 2016-2020 


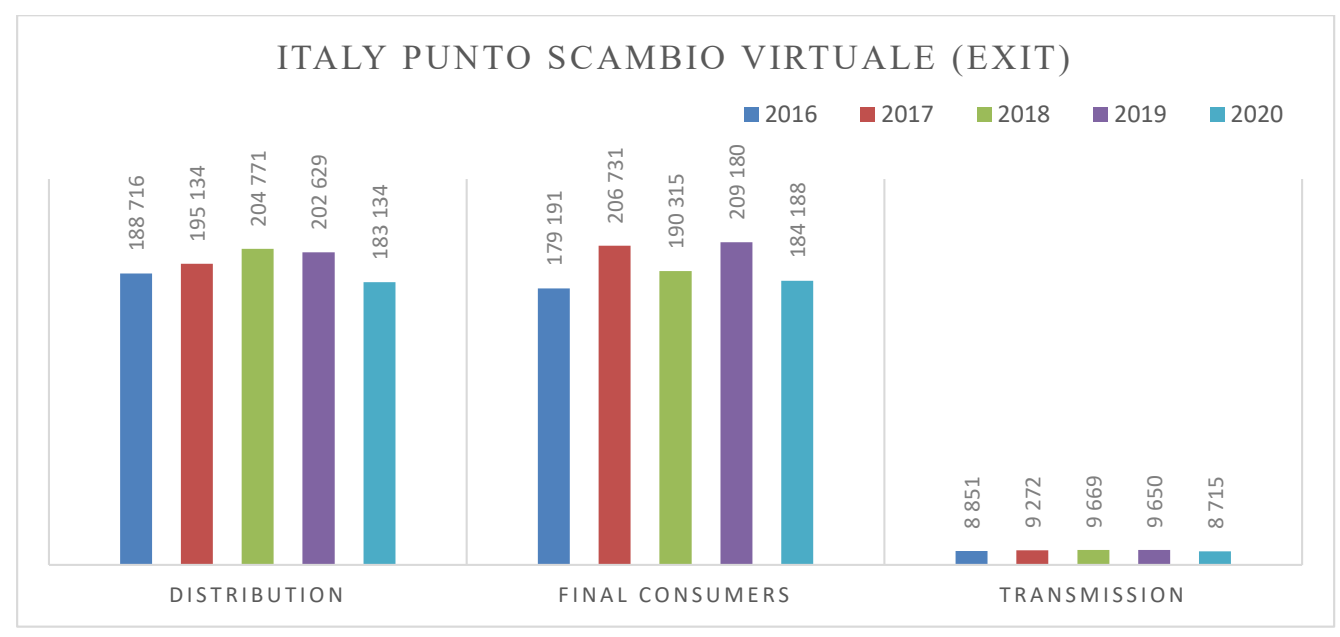

Fig. 7. Comparison of flow gas in H1 2016-2020

Source: own study based on ENTSOG

Rys. 7. Porównanie przepływów gazu dla pierwszego półrocza 2016-2020

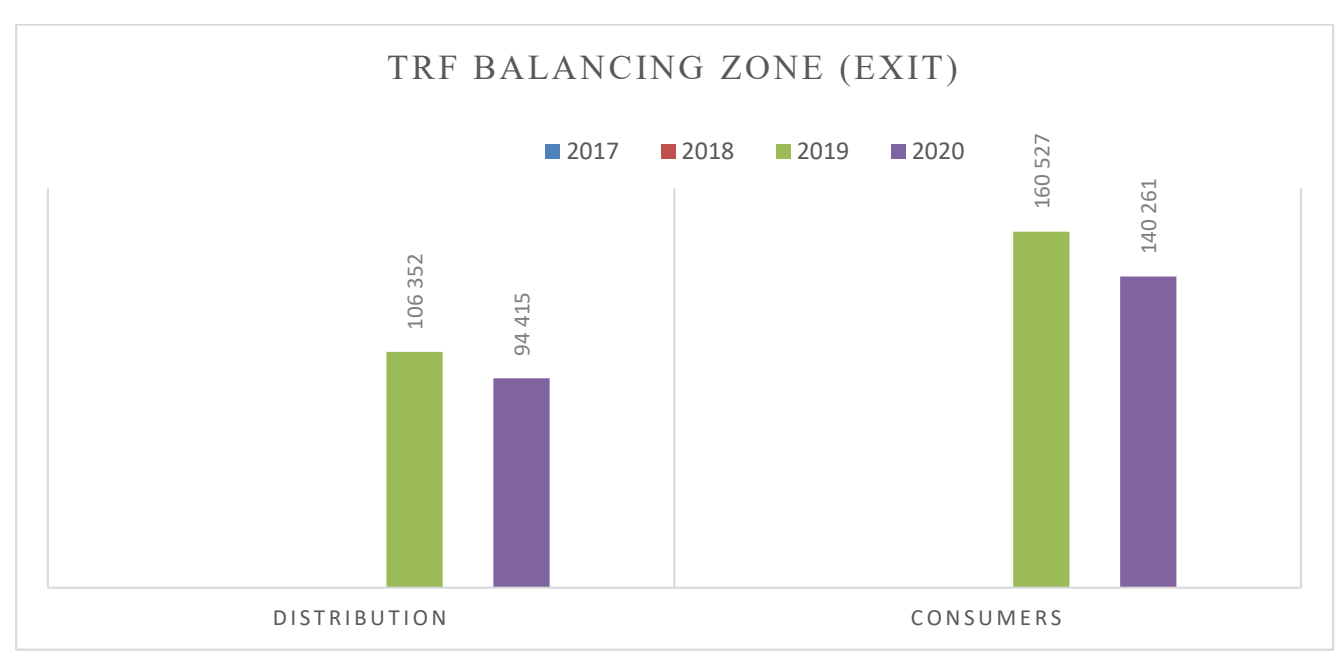

Fig. 8. Comparison of flow gas in H1 2016-2020 Source: own study based on ENTSOG

Rys. 8. Porównanie przepływów gazu dla pierwszego półrocza 2016-2020 


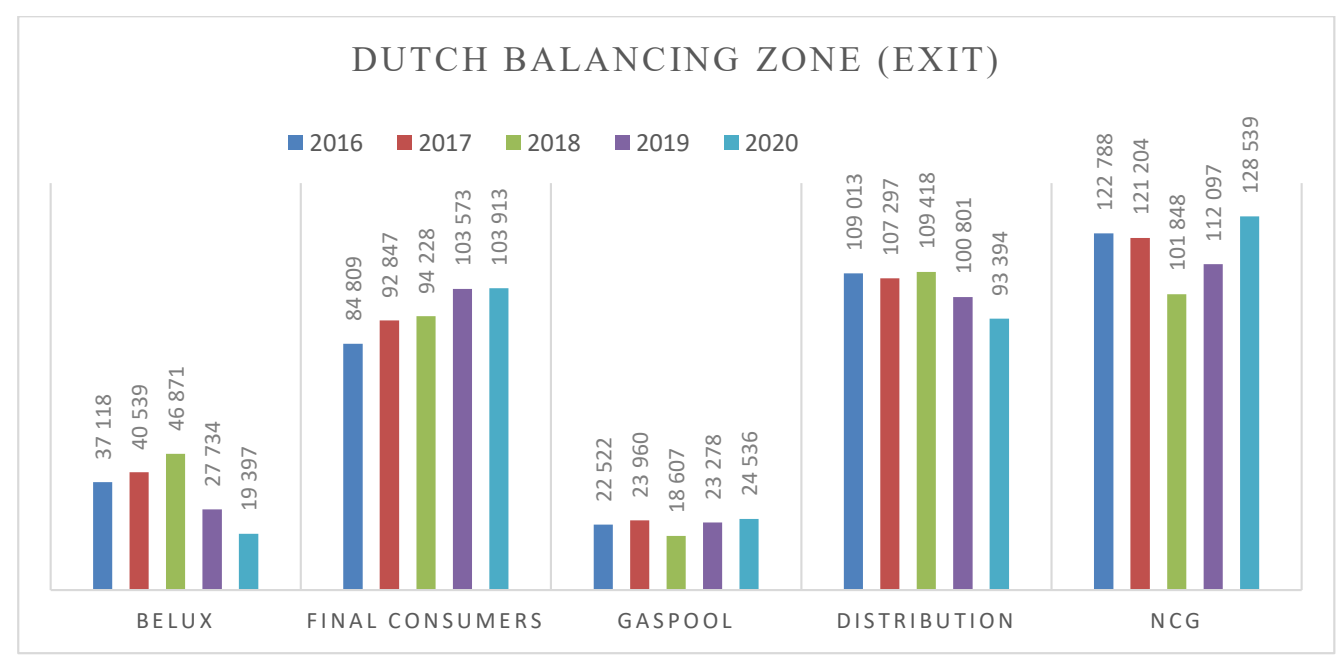

Fig. 9. Comparison of flow gas in H1 2016-2020

Source: own study based on ENTSOG

Rys. 9. Porównanie przepływów gazu dla pierwszego półrocza 2016-2020

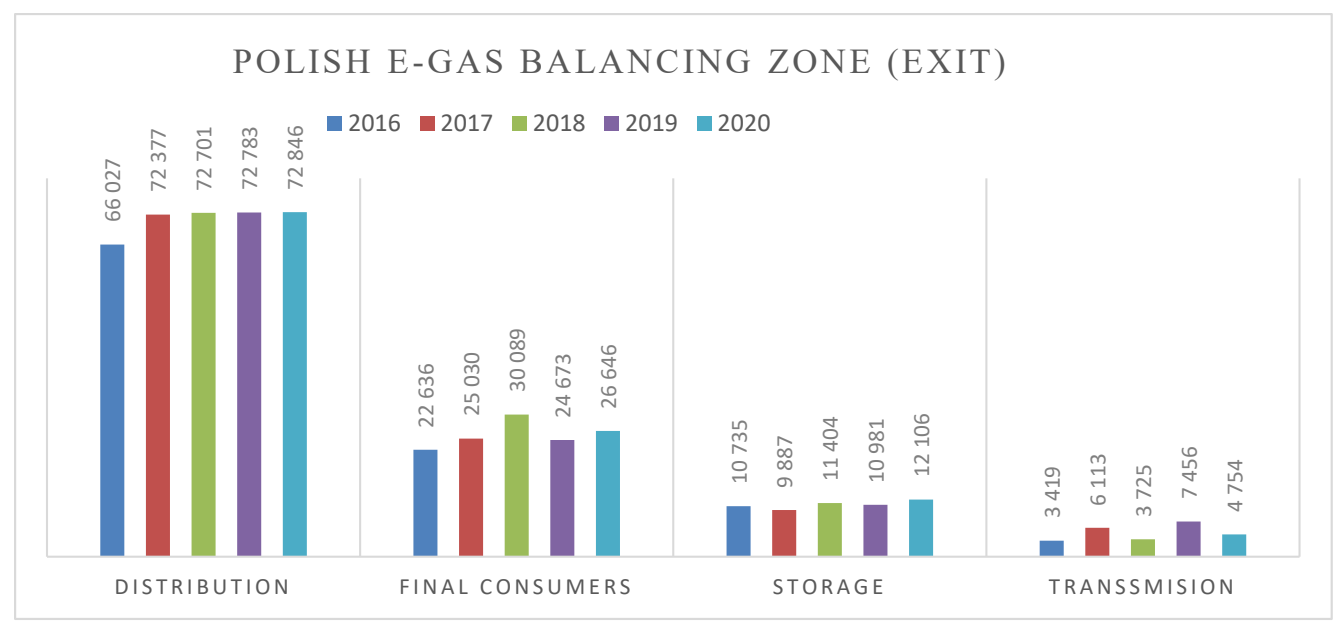

Fig. 10. Comparison of flow gas in H1 2016-2020 Source: own study based on ENTSOG

Rys. 10. Porównanie przepływów gazu dla pierwszego półrocza 2016-2020 


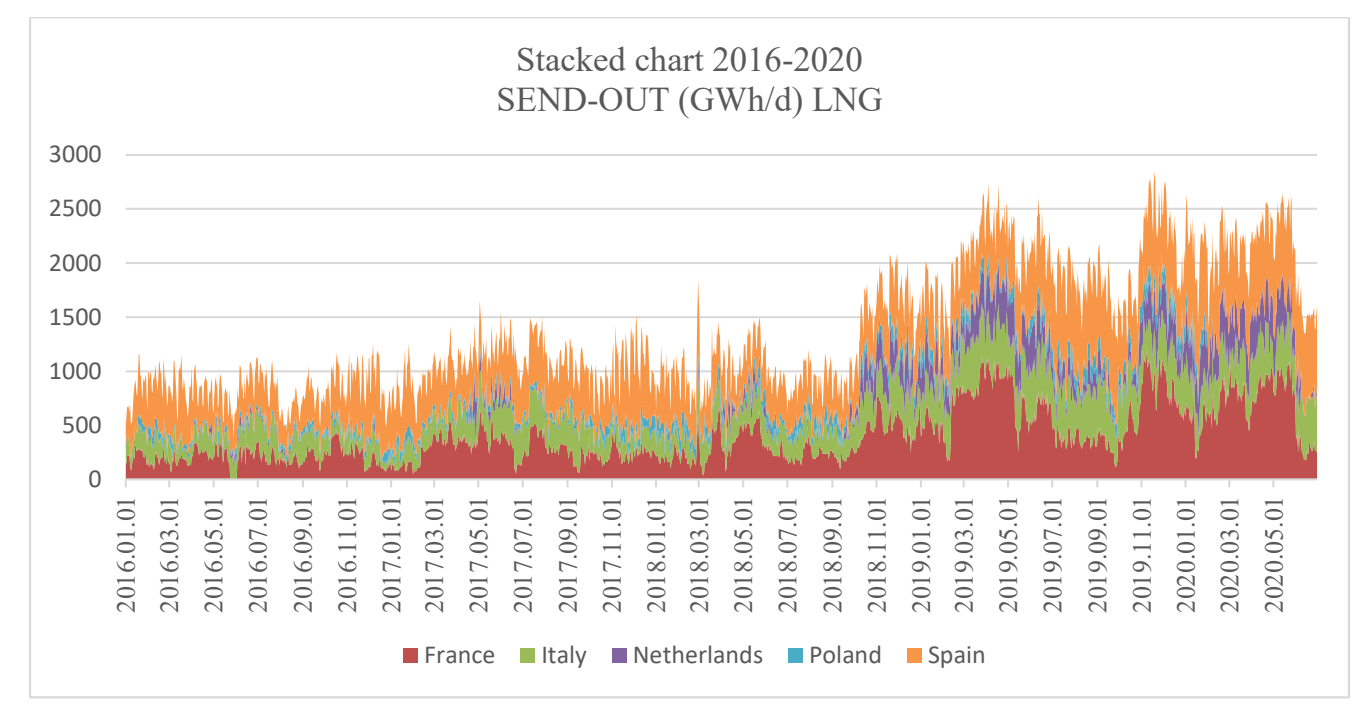

Fig. 11. Comparison of LNG Send-out in H1 2016-2020

Source: own study based on ENTSOG

Rys. 11. Porównanie wolumenów LNG (eksport) dla pierwszego półrocza 2016-2020

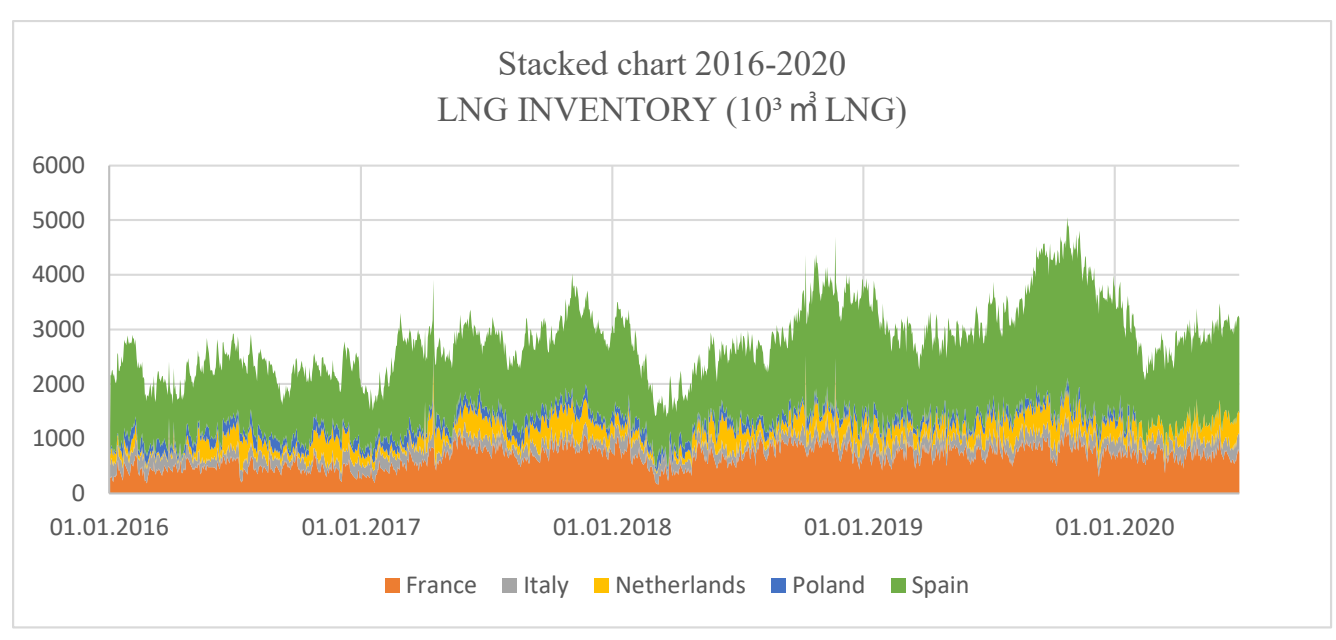

Fig. 12. Comparison of LNG (inventory) in H1 2016-2020

Source: own study based on ENTSOG

Rys. 12. Porównanie wolumenów LNG (odbiór) dla pierwszego półrocza 2016-2020 


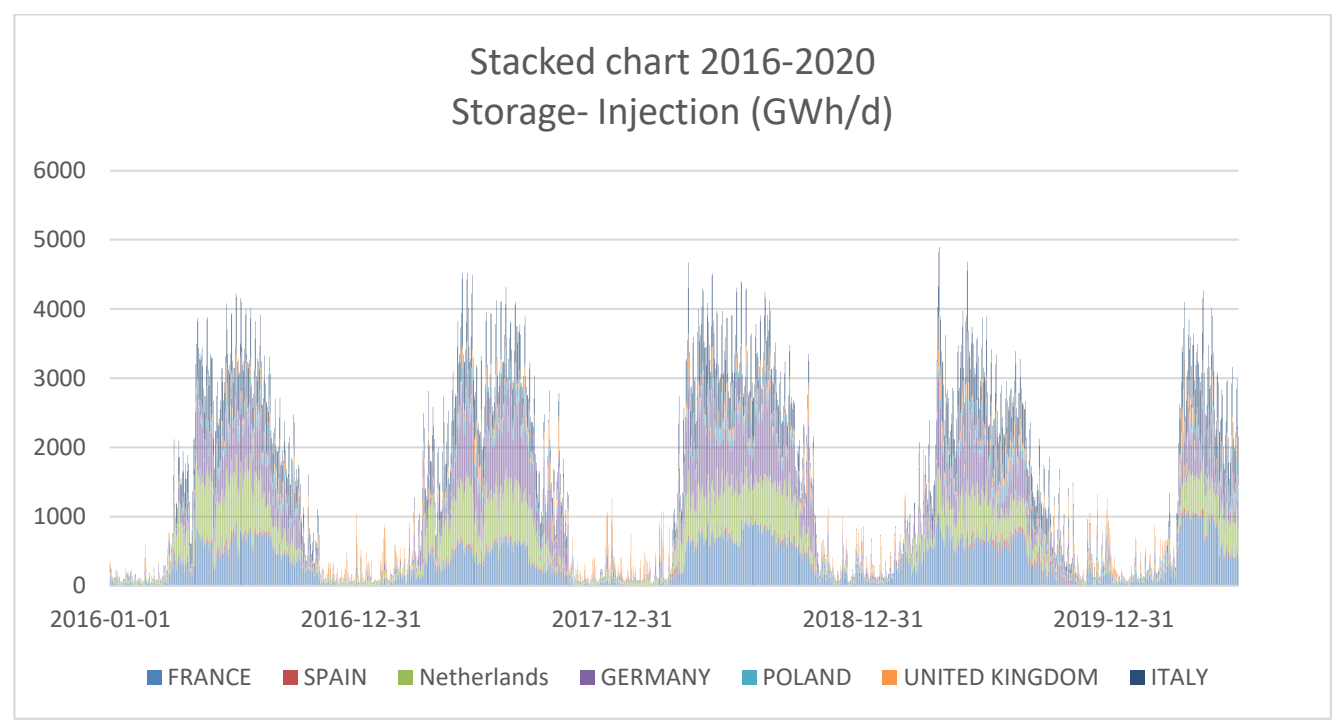

Fig. 13. Comparison of injection gas in H1 2016-2020

Source: own study based on ENTSOG

Rys. 13. Porównanie zatłoczonych wolumenów gazu dla pierwszego półrocza 2016-2020

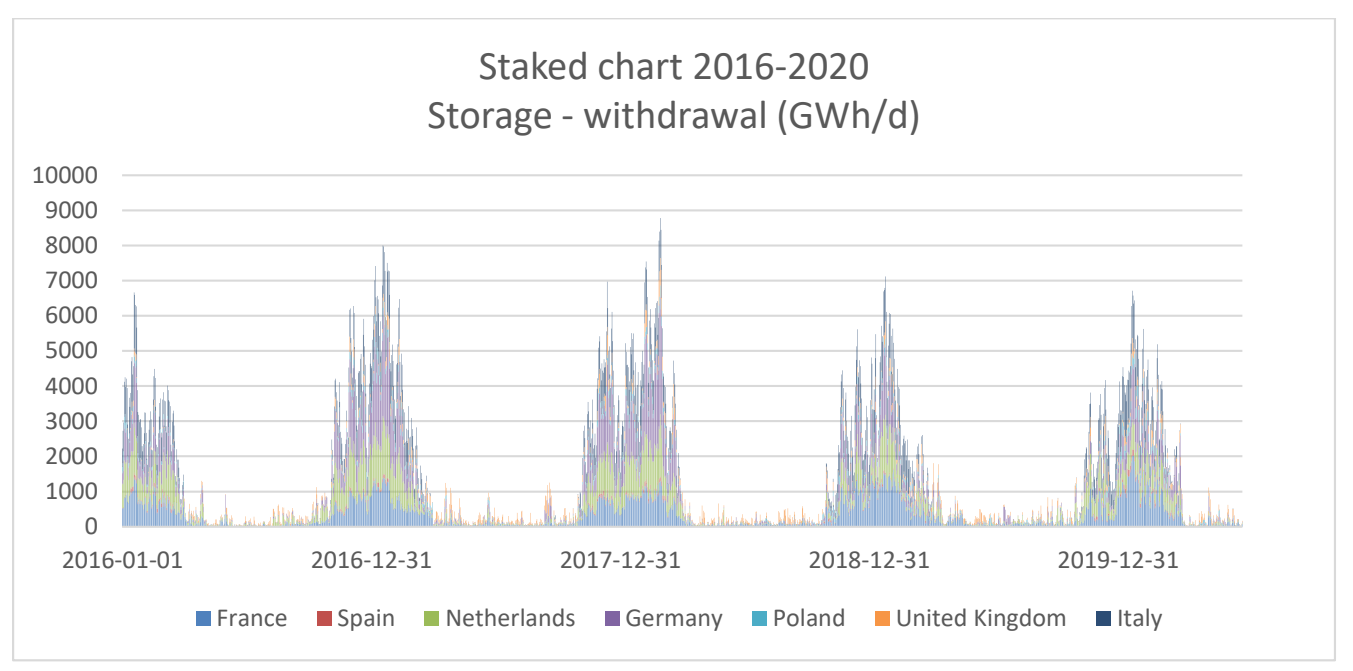

Fig. 14. Comparison of withdrawn gas in H1 2019-2020

Source: own study based on ENTSOG

Rys. 14. Porównanie odebranych wolumenów gazu dla pierwszego półrocza 2016-2020 
2.2. Natural gas prices during COVID-19 with reference to 2016-2020

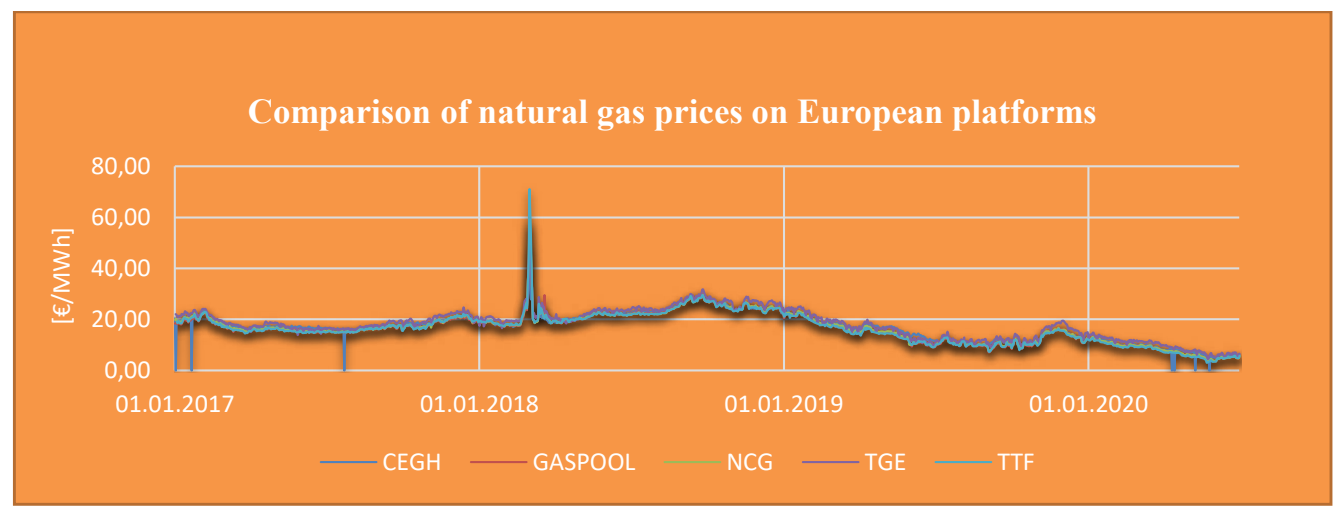

Fig. 15. Comparison of natural gas prices on European platforms (2016-2020) Source: own study based on EEX

Rys. 15. Porównanie cen gazu ziemnego na europejskich giełdach (2016-2020)

TABLE 2. Comparison of natural gas prices for household consumers (2019-2020) [kWh/Euro]

TABELA 2. Porównanie cen gazu dla gospodarstw domowych (2016-2020) [kWh/Euro]

\begin{tabular}{|l|c|c|c|c|c|c|}
\hline & $2017 \mathrm{~S} 1$ & $2017 \mathrm{~S} 2$ & $2018 \mathrm{~S} 1$ & $2018 \mathrm{~S} 2$ & $2019 \mathrm{~S} 1$ & $2019 \mathrm{~S} 2$ \\
\hline Germany & 0.0611 & 0.0609 & 0.0608 & 0.0608 & 0.0608 & 0.0588 \\
\hline Spain & 0.0667 & 0.0865 & 0.0665 & 0.0875 & 0.0736 & 0.1021 \\
\hline France & 0.0639 & 0.0695 & 0.0665 & 0.0763 & 0.0738 & 0.0839 \\
\hline Italy & 0.0704 & 0.0874 & 0.0714 & 0.0951 & 0.0769 & 0.0934 \\
\hline Netherlands & 0.0763 & 0.0815 & 0.0815 & 0.0861 & 0.0921 & 0.0965 \\
\hline Poland & 0.0417 & 0.0442 & 0.0423 & 0.0450 & 0.0473 & 0.0465 \\
\hline United Kingdom & 0.0469 & 0.0479 & 0.0465 & 0.0518 & 0.0493 & 0.0504 \\
\hline
\end{tabular}

Source: own study based on EUROSTAT 2020. 
TABLE 3. Comparison of natural gas prices for non-household consumers [kWh/Euro]

TABela 3. Porównanie cen gazu dla odbiorców przemysłowych [kWh/Euro]

\begin{tabular}{|l|c|c|c|c|c|c|}
\hline \multicolumn{1}{|c|}{ GEO/TIME } & $2017 \mathrm{~S} 1$ & $2017 \mathrm{~S} 2$ & $2018 \mathrm{~S} 1$ & $2018 \mathrm{~S} 2$ & $2019 \mathrm{~S} 1$ & $2019 \mathrm{~S} 2$ \\
\hline Germany & 0.0317 & 0.0307 & 0.0317 & 0.0315 & 0.0318 & 0.03 \\
\hline Spain & 0.0273 & 0.0267 & 0.0290 & 0.0299 & 0.0308 & 0.0307 \\
\hline France & 0.0332 & 0.0345 & 0.0352 & 0.0390 & 0.0379 & 0.0368 \\
\hline Italy & 0.0271 & 0.0253 & 0.0286 & 0.0293 & 0.0342 & 0.0296 \\
\hline Netherlands & 0.0365 & 0.0269 & 0.0384 & 0.0297 & 0.0387 & 0.0284 \\
\hline Poland & 0.0273 & 0.0276 & 0.0304 & 0.0312 & 0.0347 & 0.0336 \\
\hline United Kingdom & 0.0251 & 0.0224 & 0.0262 & 0.0279 & 0.0279 & 0.0273 \\
\hline
\end{tabular}

Source: own study based on EUROSTAT 2020.

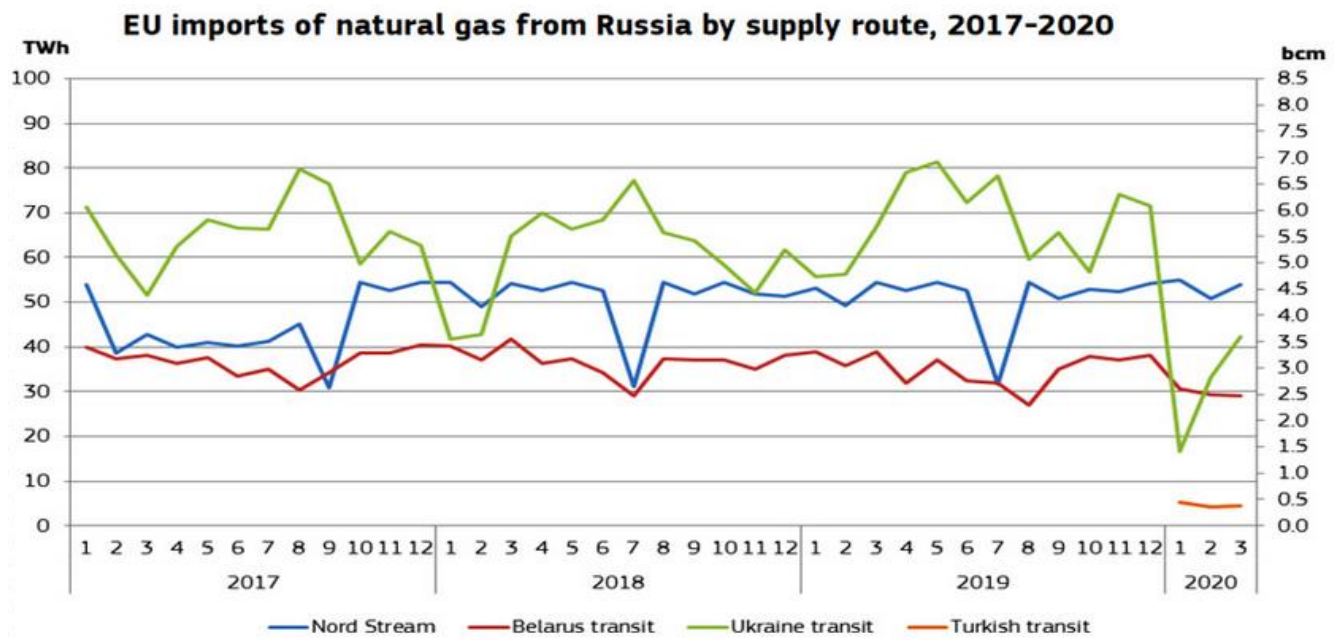

Fig. 16. EU imports of natural gas from Russia 2017-2020 Source: own study based on Market Observatory for energy EU

Rys. 16. Import gazu ziemnego z Rosji do UE 2017-2020 


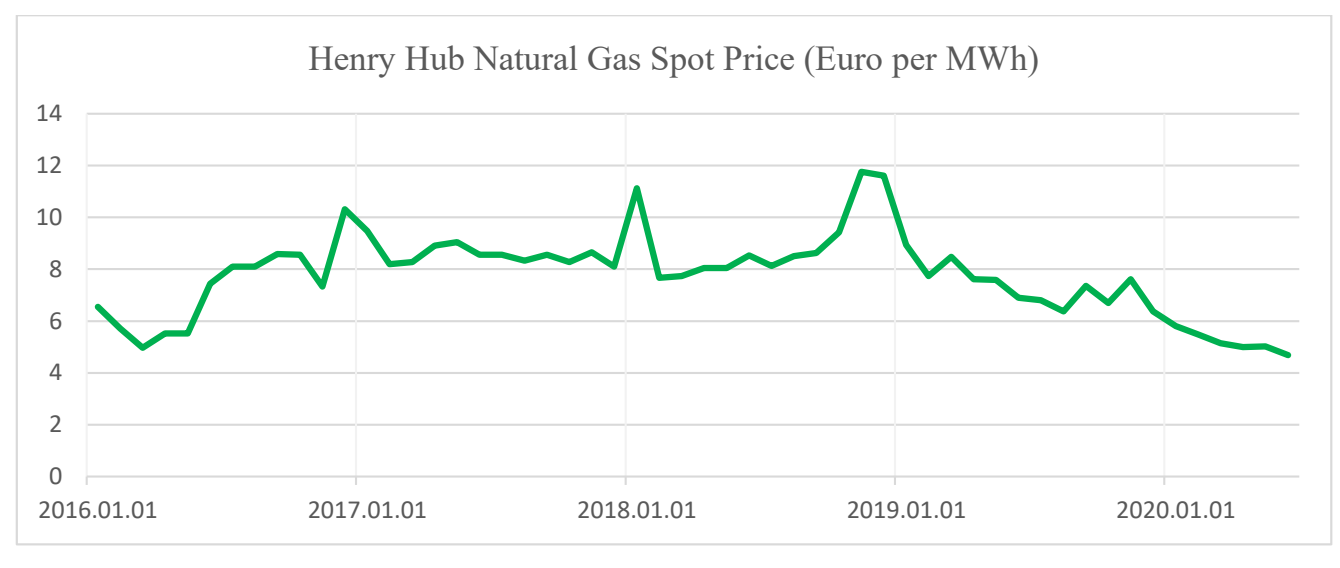

Fig. 17. Natural gas prices (2019-2020). U.S. Henry Hub

Source: own study based on the U.S. Energy Information Administration (EIA 2020)

Rys. 17. Ceny gazu ziemnego (2016-2020) na Henry Hub w USA

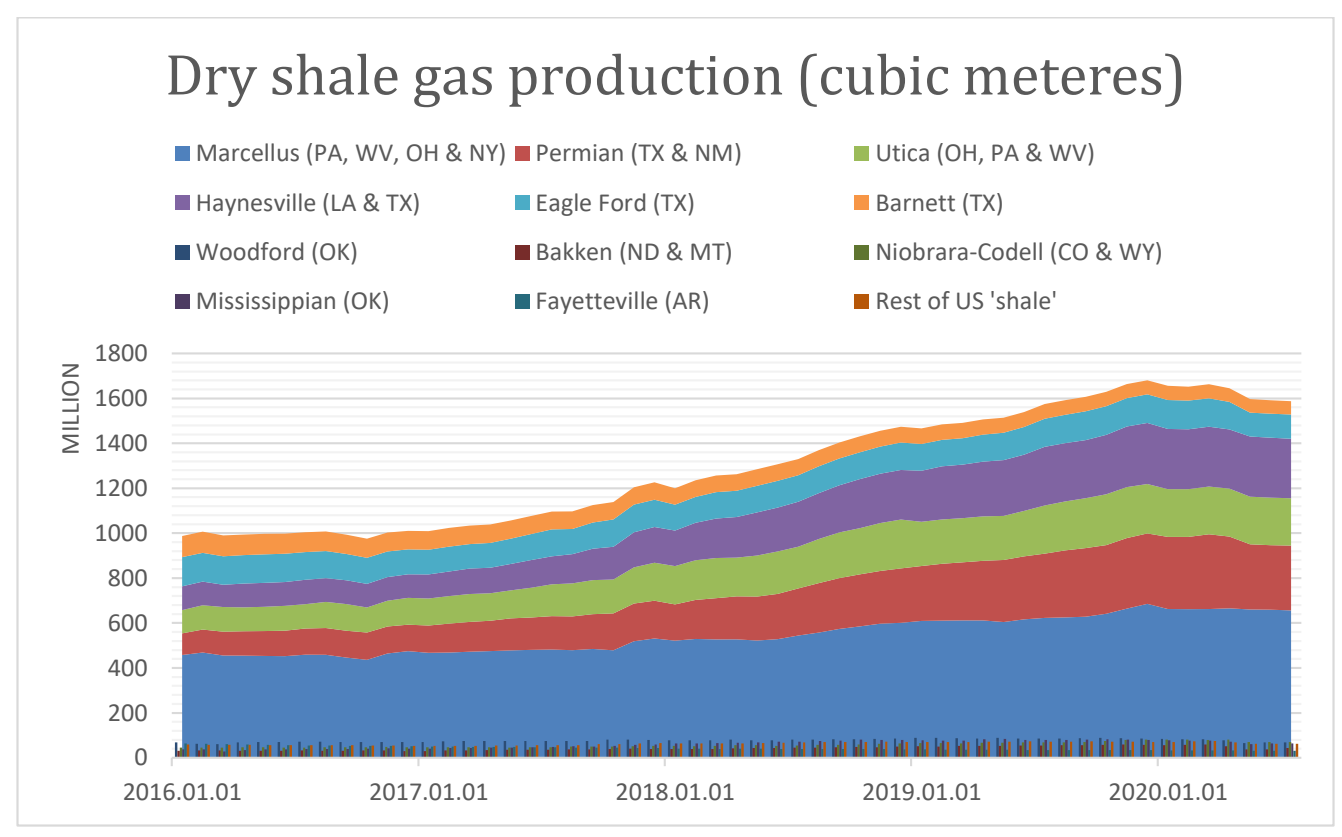

Fig. 18. Dry shale gas production in U.S. (2016-2020)

Source: own study based on the U.S. Energy Information Administration (EIA)

Rys. 18. Produkcja gazu z łupków w USA (2016-2020) 


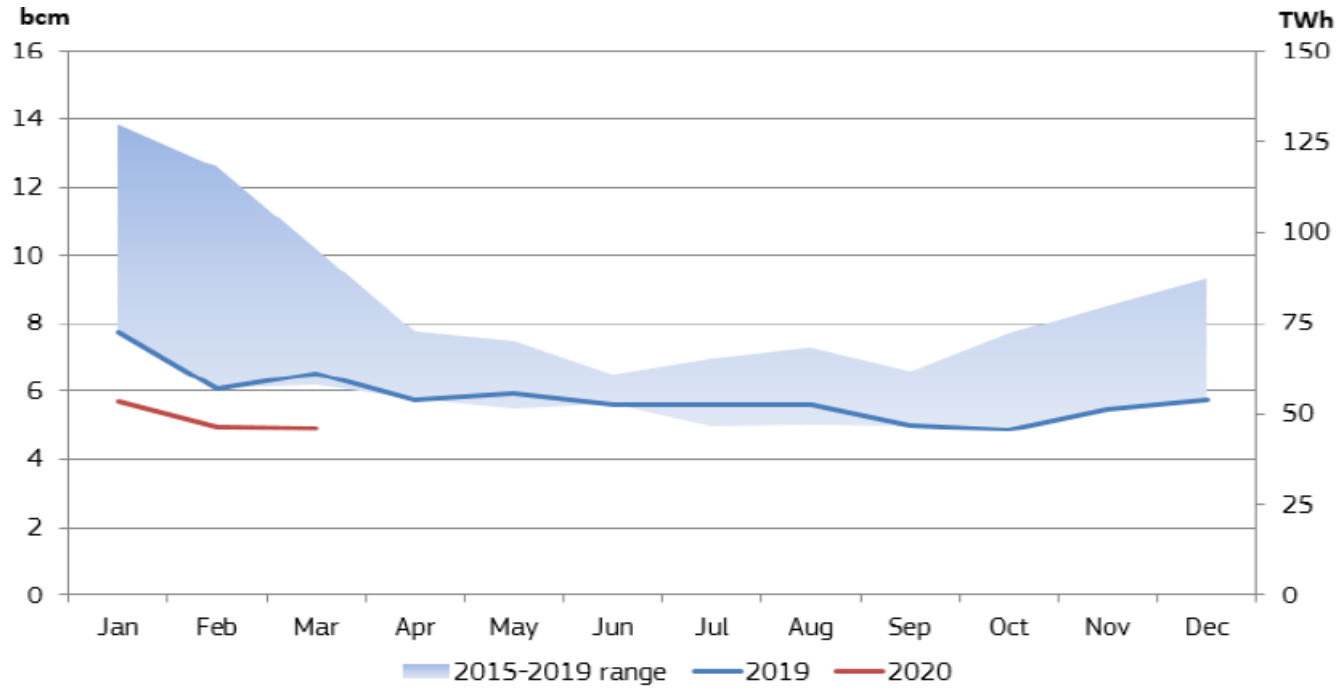

Fig. 19. Monthly gas production in the EU (y-o-y 2019-2020)

Source: own study based on the U.S. Energy Information Administration (EIA)

Rys. 19. Produkcja gazu ziemnego w UE (2019/2020) 
2.4. Weather conditions (2016-2020)

TABLE 4. Weather conditions (2016-2020)

TABela 4. Warunki pogodowe (2016-2020)

\begin{tabular}{|c|c|c|c|c|c|c|c|}
\hline \multirow{2}{*}{\begin{tabular}{|l} 
Country \\
Germany
\end{tabular}} & \multirow{2}{*}{$\begin{array}{l}\text { Weather data } \\
\max \mathrm{C}^{\circ}\end{array}$} & \multirow{2}{*}{\begin{tabular}{r|}
2016 \\
4
\end{tabular}} & \multirow{2}{*}{2017} & \multirow{2}{*}{$\frac{2018}{10}$} & 2019 & \multicolumn{2}{|c|}{2020 Time course graph } \\
\hline & & & & & 8 & 4 & \\
\hline & $\min \mathrm{C}^{\circ}$ & -2 & -2 & 5 & 7 & -3 & \\
\hline & wind $[\mathrm{km} / \mathrm{h}]$ & 5 & 13 & 17 & 31 & 10 & \\
\hline & humidity [\%] & 94 & 79 & 73 & 71 & 89 & \\
\hline & cloud [\%] & 40 & 51 & 53 & 97 & 33 & \\
\hline \multirow[t]{5}{*}{ UK } & $\max C^{\circ}$ & 8 & 9 & 8 & 10 & 7 & \\
\hline & $\min \mathrm{C}^{\circ}$ & 3 & 4 & 6 & 6 & 3 & \\
\hline & wind $[\mathrm{km} / \mathrm{h}]$ & 21 & 18 & 19 & 12 & 6 & \\
\hline & humidity [\%] & 84 & 89 & 71 & 84 & 83 & \\
\hline & cloud [\%] & 61 & 94 & 32 & 43 & 30 & \\
\hline \multirow[t]{5}{*}{ Italy } & $\max C^{\circ}$ & 12 & 11 & 14 & 11 & 13 & \\
\hline & $\min \mathrm{C}^{\circ}$ & 8 & 3 & 10 & 6 & 5 & \\
\hline & wind $[\mathrm{km} / \mathrm{h}]$ & 10 & 5 & 16 & 9 & 7 & \\
\hline & humidity [\%] & 80 & 64 & 80 & 52 & 49 & \\
\hline & cloud [\%] & 64 & 13 & 34 & 32 & 2 & \\
\hline \multirow[t]{5}{*}{ France } & $\max C^{\circ}$ & 24 & 18 & 22 & 19 & 24 & \\
\hline & $\min C^{\circ}$ & 15 & 15 & 12 & 12 & 17 & \\
\hline & wind $[\mathrm{km} / \mathrm{h}]$ & 11 & 20 & 5 & 12 & 5 & \\
\hline & humidity [\%] & 70 & 79 & 54 & 58 & 58 & \\
\hline & cloud [\%] & 2 & 89 & 17 & 38 & 69 & \\
\hline \multirow[t]{5}{*}{ France } & $\max C^{\circ}$ & 24 & 18 & 22 & 19 & 24 & \\
\hline & $\min \mathrm{C}^{\circ}$ & 15 & 15 & 12 & 12 & 17 & \\
\hline & wind $[\mathrm{km} / \mathrm{h}]$ & 11 & 20 & 5 & 12 & 5 & \\
\hline & humidity [\%] & 70 & 79 & 54 & 58 & 58 & \\
\hline & cloud [\%] & 2 & 89 & 17 & 38 & 69 & \\
\hline \multirow[t]{5}{*}{ Netherlands } & $\max C^{\circ}$ & 25 & 16 & 17 & 17 & 21 & \\
\hline & $\min \mathrm{C}^{\circ}$ & 17 & 15 & 14 & 12 & 17 & \\
\hline & wind $[\mathrm{km} / \mathrm{h}]$ & 15 & 25 & 19 & 12 & 15 & \\
\hline & humidity [\%] & 73 & 86 & 73 & 65 & 79 & \\
\hline & cloud [\%] & 4 & 100 & 75 & 64 & 71 & \\
\hline \multirow[t]{5}{*}{ Spain } & $\max C^{\circ}$ & 14 & 12 & 14 & 19 & 13 & \\
\hline & $\min C^{\circ}$ & 9 & 8 & 10 & 15 & 11 & \\
\hline & wind $[\mathrm{km} / \mathrm{h}]$ & 7 & 12 & 23 & 6 & 5 & \\
\hline & humidity [\%] & 82 & 79 & 53 & 55 & 67 & - \\
\hline & cloud [\%] & 23 & 4 & 16 & 0 & 41 & 1 \\
\hline \multirow[t]{5}{*}{ Poland } & $\max C^{\circ}$ & 24 & 15 & 26 & 22 & 19 & \\
\hline & $\min C^{\circ}$ & 12 & 12 & 14 & 14 & 14 & \\
\hline & wind $[\mathrm{km} / \mathrm{h}]$ & 4 & 22 & 8 & 9 & 10 & \\
\hline & humidity [\%] & 64 & 86 & 63 & 62 & 61 & \\
\hline & cloud [\%] & 5 & 99 & 23 & 60 & 45 & \\
\hline
\end{tabular}

Source: own study based on the accuweather.com 


\subsection{Source of energy}

TABLE 5. Source of energy supply (2016-2020) [mln toe]

TABELA 5. Źródła dostaw energii (2016-2020) [mln toe]

\begin{tabular}{|c|c|c|c|c|c|c|c|c|}
\hline \multirow[t]{5}{*}{ Germany } & & Wind, solar, etc & Oil & Hydro & Biofuels and waste & Natural gas & Coal & Nuclear \\
\hline & 2016 & 11077 & 101426 & 1767 & 30523 & 70330 & 77233 & 22052 \\
\hline & 2017 & 130407 & 102965 & 1733 & 30822 & 75341 & 71414 & 19887 \\
\hline & 2018 & 14435 & 98044 & 1545 & 30122 & 73522 & 68768 & 19804 \\
\hline & 2019 & 15964 & 101400 & 1725 & 30554 & 80218 & 54215 & 19560 \\
\hline \multirow[t]{5}{*}{ UK } & & Wind, solar, etc & Oil & Hydro & Biofuels and waste & Natural gas & Coal & Nuclear \\
\hline & 2016 & 4142 & 61062 & 464 & 11924 & 69138 & 11784 & 18689 \\
\hline & 2017 & 5308 & 61672 & 507 & 12190 & 67307 & 9564 & 18327 \\
\hline & 2018 & 6053 & 60451 & 472 & 13754 & 67849 & 8038 & 16953 \\
\hline & 2019 & 6660 & 59038 & 512 & 15670 & 67308 & 5716 & 14639 \\
\hline \multirow[t]{5}{*}{ Italy } & & Wind, solar, etc & Oil & Hydro & Biofuels and waste & Natural gas & Coal & Nuclear \\
\hline & 2016 & 9192 & 51534 & 3648 & 14360 & 58080 & 10978 & - \\
\hline & 2017 & 9331 & 52001 & 3113 & 14861 & 61549 & 9344 & - \\
\hline & 2018 & 9110 & 50914 & 4195 & 14514 & 59513 & 8556 & - \\
\hline & 2019 & 9360 & 49500 & 3936 & 14758 & 60826 & 5793 & - \\
\hline \multirow[t]{5}{*}{ France } & & Wind, solar, etc & Oil & Hydro & Biofuels and waste & Natural gas & Coal & Nuclear \\
\hline & 2016 & 3126 & 73028 & 5231 & 17641 & 38289 & 9112 & 105056 \\
\hline & 2017 & 3572 & 73457 & 4299 & 17486 & 38492 & 9891 & 103796 \\
\hline & 2018 & 4036 & 70998 & 5613 & 17488 & 36976 & 9034 & 107596 \\
\hline & 2019 & 4630 & 69889 & 4949 & 18068 & 37784 & 7364 & 103966 \\
\hline \multirow[t]{5}{*}{ Netherlands } & & Wind, solar, etc & Oil & Hydro & Biofuels and waste & Natural gas & Coal & Nuclear \\
\hline & 2016 & 947 & 27402 & 9 & 3602 & 30031 & 10146 & 1032 \\
\hline & 2017 & 1209 & 27859 & 5 & 3674 & 31022 & 9148 & 887 \\
\hline & 2018 & 1351 & 26989 & 6 & 3912 & 30729 & 8213 & 916 \\
\hline & 2019 & 1641 & 25297 & 6 & 4316 & 32017 & 6419 & 1019 \\
\hline \multirow[t]{5}{*}{ Spain } & & Wind, solar, etc & Oil & Hydro & Biofuels and waste & Natural gas & Coal & Nuclear \\
\hline & 2016 & 7402 & 50135 & 3129 & 7186 & 25040 & 10540 & 15277 \\
\hline & 2017 & 7594 & 52862 & 1575 & 7578 & 27266 & 12810 & 15123 \\
\hline & 2018 & 7308 & 52926 & 2952 & 8009 & 27082 & 11254 & 14530 \\
\hline & 2019 & 8183 & 51863 & 2104 & 7941 & 30879 & 4913 & 15229 \\
\hline \multirow[t]{5}{*}{ Poland } & & Wind, solar, etc & Oil & Hydro & Biofuels and waste & Natural gas & Coal & Nuclear \\
\hline & 2016 & 1168 & 25792 & 184 & 8143 & 14633 & 49187 & - \\
\hline & 2017 & 1373 & 29028 & 220 & 8191 & 15445 & 49421 & - \\
\hline & 2018 & 1207 & 29734 & 169 & 8659 & 16124 & 49409 & - \\
\hline & 2019 & 1442 & 30083 & 168 & 9234 & 16925 & 44800 & - \\
\hline
\end{tabular}

Source: own study based on EUROSTAT 2020.

\section{Analysis results and discussion}

The collected historical data of gas flows showed low demand for natural gas and for total energy. In the United Kingdom the level was $11 \%$ lower than this time last year. The lowest point was the seven-day period ending April 14 - the Tuesday after the Easter weekend around the height of Covid-19 deaths and the peak of the crisis. Chart (Fig. 3) showed that National Grid Gas plc, the national transmission operator of Great Britain, transferred approximately 
99,000 GWh in the first half of 2020, which compared to the last four years amounted to approximately $130,000 \mathrm{GWh}$. Gas consumption heading into the summer is considerably lower than the levels typically observed in April/May. The impact of the lockdown measures and one of the warmest Aprils on record have contributed to low levels of gas demand on the National Transmission System. Gas storage in the UK is well-stocked at a five-year high for this time of year. With the continued arrival of LNG tankers to UK terminals, the gap between gas supply and demand in the country continues to widen. These factors point towards a continual decline in UK gas prices emerging from the spring, with the already low day-ahead contract likely to extend losses further into the summer (National Grid UK 2020). A large amount of accumulated gas and low demand may have led to the lowest gas in the United Kingdom for industrial customers and households (Tables 2 and 3). As for the UK's energy supply, there is a general increase in demand for energy from natural gas, but a decline in demand for coal (Table 5).

Italy registered more deaths than anywhere else in the world and accounts for more than a third of all global mortalities (WHO 2020). Chart 8 of gas supplies to the distribution area showed a decrease in consumption. In the last four months, the operator of Snam Rete Gas S.p.A. provided the distribution area with 188,000-200,000 GWh (upward trend), while in the same period in 2020 it amounted to almost $183,000 \mathrm{GWh}$. The competitiveness of natural gas increased considerably compared to coal and hydroelectric energy in the Italian market (Table 5) In addition, 2019, was characterized by a particularly mild winter compared to normal temperatures, with high storage level sand higher than usual regasification rates averaging $85 \%$ (97\% in Rovigo (Qatarigas), 94\% in LNG Toscana(US gas) and 64\% in Panigagli a(Algerian gas) ) when compared to less than $25 \%$ in previous years (GECF 2020).

In France, a 11 percent-decrease in natural gas consumption was reported in distribution and 12 percent in final consumers (Fig. 8) compared to the previous year. A decline in nuclear energy and coal has been noted in France (Table 5). Additionally, it must be stated that the energy supplied to industrial recipients in France is the most expensive in relation to the other surveyed countries. (Table 3) Compared to other countries, the average annual minimum and maximum temperature in France has a strong upward trend (Table 5). It should must be mentioned that France was the largest LNG importer in Q2 2019 and in France the consumption went up by $37 \%$ in 2019. Therefore France is one of the leading countries for which a sharp drop in gas consumption was noticed compared to the previous year.

The Netherlands report focuses on the impacts of COVID-19 across supply and demand for oil \& gas and LNG. With the ease in lockdown measures in the Netherlands, the economic activity is rebounding with a growing demand for fuel. The Netherlands oil and gas demand is expected to return to 2019 levels only after 2023 or 2024. In addition it is characteristic for the Netherlands that the transmission for industry remained the same as in the previous year, only the consumption for households decreased to the previous years.

The Spanish gas market hit by coronavirus impacted the natural gas demand. The Spanish lockdown squashed front month energy prices. Expectations of plummeting demand in Spain due to a national lockdown hit the front month power contract by more than EUR 3/MWh on March 16 (ICIS 2020). Figure 3 showed that the introduction of the lockdown also resulted in 
lower consumption of natural gas. Importantly, energy consumption from coal fell by as much as 50\% in 2019 compared to the previous years in the first six months. The coming months show data on energy consumption from coal (Table 5).

Poland reacted the fastest by introducing restrictions to the news about the first infected person in the country. Figure 3 showed that in Poland, despite the epidemic, gas consumption among end users increased compared to last year. This is also caused by huge investments in the development of gas network infrastructure and others (GAZ-SYSTEM 2020). On November 15, 2019, PGNiG provided GAZPROM with a declaration of will to end the so-called Yamal contract as of December 31, 2020. Generally, it was noticed that gas imports from Russia decreased significantly (Fig. 16). Tables 2 and 3 show that the price of gas for households and end users in Poland is one of the lowest. A decrease in the consumption of coal was also observed, while an increase in the consumption of energy from natural gas, renewable energy sources was observed. There is no nuclear energy in Poland and in Italy (Table 5).

\section{Conclusions}

The global spread of the coronavirus is taking a devastating human toll and will represent an unprecedented shock for the world's economy. Globally energy demand has been changed dramatically. The amounts of energy supply have changed, as well as the energy sources. With the drop in demand in Europe and the world, record low prices, which are accompanied by a slump in the oil market, as well as the deepening economic crisis caused by COVID-19 record gas prices, it can be concluded that the decarbonation process is an opportunity to develop other sources of energy supply, including natural gas. Last winter Europe had the warmest temperatures on record, resulting in fewer heating days. The abnormally high temperatures in the last year curbed energy demand. This proved that temperature is a very important factor in the process of shaping gas consumption. Additionally, the introduced restrictions and the fear of losing a job meant that in the surveyed countries, people started to save more and spend less money on any investments. The lockdown introduced a reduction in the movement of economies, which is also a decisive factor in the energy demand for the production of goods. The continuing COVID-19 crisis has complicated geopolitics in many different ways. The route supplies of gas is one prominent example. Conducting a geo-political game on the gas market of individual countries depends on the situation and depends on the common policy of the European Union but also on the specificity of a given country. Increasing LNG imports and extensive gas storage have had an impact on EU gas prices. This applies to the indicated countries, but also to the entire global gas market. Overall, significant and protracted blocking efforts will further reduce the industry and power generation demand for natural gas. There are many factors impacting the reduced demand and COVID-19 contributed further as an important factor. Assessing the impact of the coronavirus on major gas sectors will be somewhat measurable in the coming weeks as there is no data available to serve as an accurate forecast. 


\section{References}

BP 2020. Statistical Review of World Energy. [Online] https://www.bp.com/en/global/corporate/energy-economics/statistical-review-of-world-energy.html [Accesed: 2020-09-01].

CNBC 2019. Ukraine and Russia look to strike new gas deal amid US sanctions threat. [Online] https:// www.cnbc.com/2019/12/16/ukraine-and-russia-look-to-strike-gas-transit-deal.html [Accessed: 202005-21].

DG Energy 2020. Quarterly Report on European, Luxembourg: Gas Markets Directorate-General for Energy European Commission, Volume 13.

EC 2020. European Commission. Communication: Coordinated economic response to the COVID-19 Outbreak, $\operatorname{COM}(2020) 3$.

EEX. [Online] https://www.eex.com/en/ [Accessed: 2020-09-01].

ENTSOG. [Online] https://www.entsog.eu/ [Accessed: 2020-09-05].

EUROSTAT 2020. Impact of COVID-19 on household consumption and saving. [Online] https://ec.europa. eu/eurostat/web/products-eurostat-news/-/DDN-20200806-2 [Accessed: 2020-09-20].

GAZ-SYSTEM 2020. Our investments. [Online] https://en.gaz-system.pl/our-investments/ [Accessed: 2020-09-15].

GECF 2020. COVID-19 and its Implications on the Italian Natural Gas Market. [Online] https://www. gecf.org/_resources/files/events/gecf-expert-commentary---covid-19-and-its-implications-on-the-italian-natural-gas-market/covid-19-and-its-implication-in-the-italian-gas-market.pdf [Accessed: 202009-15].

Hedwedge 2020. EEX to enable trading for new German Gas market Trading Hub Europe (THE) with existing NCG products. [Online] https://www.hedgeweek.com/2020/09/18/289796/eex-enable-tradingnew-german-gas-market-trading-hub-europe-existing-ncg-products [Accessed: 2020-09-22].

ICIS 2020. Coronavirus impact on energy markets. [Online] https://www.icis.com/explore/resources/ news/2020/03/19/10482507/topic-page-coronavirus-impact-on-energy-markets [Accessed: 2020-08-10].

IEA 2020. Energy Policy Review, Paris: International Agency (IEA), 170 pp.

Kosowski et al. 2010 - Kosowski, P., Stopa, J. and Rychlicki, St. 2010. Gas market in Poland in the years 2003-2009 and forecasts for 2010-2012 (Analiza rynku gazu ziemnego w Polsce w latach 2003-2009 i prognozy na lata 2010-2012). Nafta-Gaz 66(11), pp. 993-999 (in Polish).

Market Observatory for energy EU. [Online] https://ec.europa.eu/energy/data-analysis/market-analysis_pl [Accessed: 2020-09-01].

McKinsey \& Company 2020. Oil and gas after COVID-19: The day of reckoning or a new age of opportunity? [Online] https://www.mckinsey.com/industries/oil-and-gas/our-insights/oil-and-gas-after-covid19-the-day-of-reckoning-or-a-new-age-of-opportunity [Accessed: 2020-05-20].

National Grid UK 2020. Data and operations. [Online] https://www.nationalgrid.com/uk/gas-transmission/ data-and-operations/transmission-operational-data/useful-operational-information [Accessed: 202009-19].

Olayele, F. 2015. The Geopolitics of Oil and Gas. IAEE, Second Quarter 2015, p. 29.

[Online] https://www.accuweather.com [Accessed: 2020-09-06].

RBAC 2020. Inc. Energy Industry Forecasting Systems. COVID-19 Impact Gas in Europe. [Online] https:// rbac.com/covid-19-impact-on-natural-gas-in-europe/ [Accessed: 2020-09-28].

U.S. EIA 2020. U.S. Energy Information Administration, Analysis\&Projections. [Online] https://www.eia. gov/naturalgas/ [Accessed: 2020-09-01].

University of Chicago. A view from the Grid. [Online] https://home.uchicago.edu/ scicala/papers/real time_EU/real_time_EU.pdf [Accessed: 2020-09-16].

WHO 2020. Statistics [Online] https://www.who.int/countries/ita/ [Accessed: 2020-20-21].

90 


\section{Proces kształtowania się konsumpcji oraz cen gazu ziemnego w krajach europejskich $w$ aspekcie rozprzestrzeniania się epidemii COVID-19}

\section{Streszczenie}

Jak wiadomo, zużycie gazu i jego ceny zależą od wielu czynników, w tym czynników lokalnych, geopolitycznych, rozwoju infrastruktury gazowej (w tym LNG), kosztów dystrybucji i wydobycia - np. ze złóż niekonwencjonalnych (np. gaz z łupków). Globalny rynek gazu zależy przede wszystkim od relacji gospodarczych między dużymi producentami gazu a importerami, np. USA-Chiny, Bliski Wschód / USA - Rosja itp. W poszczególnych krajach cena uzależniona jest również od zawartych umów i kierunków dostaw. Należy również wspomnieć, że zużycie gazu jest uzależnione od warunków pogodowych, typu dnia w roku (święto, dzień roboczy, miesiąc) oraz sytuacji gospodarczej. Jaki wpływ na europejski rynek gazu ziemnego ma zupełnie bezprecedensowa sytuacja - pojawienie się epidemii COVID-19?

Analizowany problem badawczy dotyczył w szczególności dwóch obszarów: zużycia gazu i jego cen w wybranych krajach europejskich w aspekcie rozprzestrzeniania się epidemii COVID-19 w odniesieniu do danych historycznych z lat 2016-2019. Wytypowano siedem krajów europejskich należących do Europejskiej Sieci Operatorów Systemów Przesyłowych Gazu (ENTSOG), w przypadku których w ostatnim roku zaobserwowano najwyższe krajowe zużycie gazu ziemnego. W odpowiedniej kolejności są to: Niemcy, Wielka Brytania, Włochy, Francja, Holandia, Hiszpania, Polska. Dane zostały pobrane od operatorów systemów przesyłowych (OSP) dla każdego z tych krajów. Ponadto artykuł przedstawił informacje o terminach wprowadzonych ograniczeń rządowych (restrykcje), wolumenach kontraktów LNG, wielkościach zatłaczania / odbioru do podziemnych magazynów gazu.

SŁowa KLUCZOWE: konsumpcja gazu, COVID-19, ceny gazu ziemnego, restrykcje 
